\title{
Cuerpo, ley y \\ ¿ sacrificialidad. La \\ antropología de Franz J. \\ Hinkelammert, de Carlos Molina Velásquez
}

\author{
Gabriel Girón Herrera \\ Universidad Evangélica de El Salvador
}

Carlos Molina Velásquez nos presenta una obra de mucha relevancia académica, no sólo por analizar el pensamiento crítico-antropológico de Franz Hinkelammert, sino también por hacerlo accesible a aquellos que aún no han tenido contacto con la extensa obra de este pensador. Algo innegable es que somos un país consumidor de conocimientos, que aceptamos de manera asuntiva los modelos económicos, sociales, educativos y políticos impuestos por los países dominantes, sin antes hacer una revisión crítica de ellos. Esto nos coloca en una posición complicada, primero porque debemos ser capaces de ver los elementos ideológicos implícitos en los diversos sistemas que llegan a nosotros y, segundo, ser capaces de leer y analizar de manera crítica la realidad actual. Aquí es donde la obra de Carlos Molina cobra especial relevancia, porque nos acerca al pensamiento crítico de Hinkelammert, que de por sí no es tarea fácil, ya que implica conocer ampliamente sus escritos principales y estructurar, a manera de hilo conductor, las ideas y categorías hinkelammertianas que nos ayuden a leer los problemas actuales.

Para aprovechar las herramientas interpretativas ofrecidas por Carlos Molina, primeramente necesitamos instalarnos contextualmente, es decir, leer a Hinkelammert ubicándonos en la realidad histórica que vivimos; estar a la altura de nuestro momento histórico. También se hace 
necesaria una instalación modal, esto significa que debe surgir en el lector una respuesta a los cambios y problemáticas actuales que deben desarrollarse desde nuestro presente, porque su sentido solamente se hace comprensible desde el aquí y el ahora. De forma introductoria, el autor deja claro que el pensamiento crítico de Hinkelammert nos introduce a un mundo interdisciplinario, ya que en él confluyen la filosofía, la economía y la teología, que funcionan como una reconstitución del pensamiento crítico contemporáneo, ya que éste es una crítica desde adentro, es decir, una autocrítica.

En Cuerpo, ley y sacrificialidad se nos presenta una labor crítica que se centra, en primera instancia, en la idea del sujeto occidental que se ha entendido y enseñado como un sujeto incorpóreo, abstracto, espiritualizado, carente de su materialidad social y que al ser despojado de su cuerpo humano es sacrificado por el despotismo de la ley que lo aplasta, lo deshumaniza y lo somete violentamente. Esta abstracción del sujeto concreto ha sido posible gracias al cristianismo occidental que ha formulado una antropología trascendental que desemboca en la espiritualización de la materialidad de la vida.

Una segunda instancia crítica es dirigida a la ley como mecanismo de control y a la racionalidad formal que, como lo expresa Carlos Molina: "deviene en un mercado absolutizado". Con esto, Hinkelammert pretende recuperar la prioridad del ser humano, ya que se constituye como una crítica frontal a las abstracciones o espiritualizaciones que la racionalidad occidental ha elaborado sobre el sujeto concreto. Se trata de la recuperación del sujeto viviente, de su corporeidad, de su condición real concreta, en contraposición a esa abstracción institucional que mata y somete al sujeto viviente, que le vuelve en mercancía, en fuerza de trabajo fetichizado por el mercado neoliberal.

Este aspecto nos introduce al análisis crítico que hace Hinkelammert al capitalismo neoliberal, al mercado que demanda sacrificios humanos constantes, a las políticas de un modelo económico hecho "dios". Giorgio Agamben refiriéndose a esto expresa: "Dios no ha muerto, se convirtió en dinero", esa expresión muestra el endiosamiento del capital en detrimento de la vida humana; el capital por encima de lo fáctico y lo vital. Por eso, siguiendo esta línea de análisis propuesta por Hinkelammert, se hace necesario retornar a la fenomenología de la vida real y de lo concreto. En este sentido, se hace necesaria una crítica dirigida al mercado neoliberal y a lo jurídico, ya que éste es para Hinkelammert el factor determinante y posibilitante de la relación de los objetos como mercancía y que dada esta relación surge "la propiedad privada de los 
medios de producción". Este aspecto legal posibilita que los propietarios se reconozcan como propietarios privados, es decir, como guardianes de las mercancías. Esta relación de superestructura conlleva la ausencia de algo, pero que al mismo tiempo está presente, Hinkelammert le llama a esto "la presencia de una ausencia", esto es lo humano, lo que siempre está ausente en estas relaciones entre los propietarios privados y las estructuras de dominación. Ésta se vuelve una dura crítica al humanismo burgués, que cree posible poder humanizar el capitalismo y las relaciones de explotación y dominación, que en realidad no hacen más que deshumanizar y oprimir al ser humano concreto.

En una tercera instancia, Carlos Molina plantea la cuestión de la inversión de los derechos humanos. Esto implica que lo institucional se apodera de la humanidad del sujeto viviente y de sus derechos humanos, ya que este ser humano despojado de su corporeidad sólo tendrá derechos humanos en la medida que se someta a las instituciones y al mercado absolutizado. De esta manera, este ser humano "libre" recibirá sus derechos humanos de las instituciones que le oprimen y le dominan. De esta manera, Carlos Molina nos muestra que Hinkelammert apunta abiertamente a que el ser humano se encuentra subordinado al fetiche-mercado como mecanismo de dominación y que esta relación de dominio es absoluta. Esto deriva en lo que Molina llama "la inversión de los derechos humanos". La sociedad burguesa del siglo XVIII instituyó una forma de organización centrada y unificada en torno a "la propiedad privada como derecho fundamental", es decir, la persona humana se redujo a la figura de un individuo propietario y todos los otros derechos humanos como la integridad corporal y el ejercicio de la ciudadanía se subordinaron a éste como inferiores.

En este sentido, el mercado global deviene en una institución absolutizada, las burocracias privadas de las empresas de producción mundial se vuelven poderes no controlados que de manera sutil no son elegidos mediante procedimientos públicos - verdaderamente democráticos. Estas corporaciones o multinacionales son las que dictan las políticas a los gobiernos, controlan los medios de comunicación y defienden su poder despótico en "nombre de los derechos humanos", así se han convertido en la gran aplanadora del propio ser humano. Con estos aportes podemos comprender mejor la racionalidad o lógica invertida de los derechos humanos analizada por Hinkelammert, que ha posibilitado la expansión imperialista europea sobre las otras regiones, la colonización del mundo no europeo, el estado de guerra (esas políticas de invasión y aniquilamiento), la legitimación del trabajo forzado por esclavitud y la 
expropiación legítima de los pueblos indígenas de América del Norte.

Cuerpo, ley y sacrificialidad se posiciona como una obra crítica medular que abarca aspectos actuales de gran importancia como el sujeto trascendental construido por Occidente, al sujeto incorpóreo, espiritualizado por el cristianismo, la razón instrumental, los valores abstractos y la subjetividad trascendental. La crítica Hinkelammertiana también abarca los utopismos acríticos, esas propuestas esperanzadoras ciegas de realidad, que son las causantes de los mecanismos de deshumanización desplegados por la cultura moderna occidental a lo largo de cinco siglos de historia. Este mantenimiento de orden y control ejercido por un sistema neoliberal e inhumano es el blanco del trabajo bien logrado que hace Carlos Molina del pensamiento de Hinkelammert.

Espero que esta obra ayude al lector a instalarse contextualmente en la realidad histórica que se vive actualmente $y$, desde este posicionamiento crítico, logre comprender mejor la complejidad de los cambios y las problemáticas filosóficas, políticas, sociales y económicas del presente. 